Nig J. Biotech. Vol. 32 (2017) $41-52$

ISSN: 01891731

Available online at

http://www.ajol.info/index.php/njb/index

and www.biotechsocietynigeria.org

DOI: http://dx.doi.org/10.4314/njb.v32i1.7

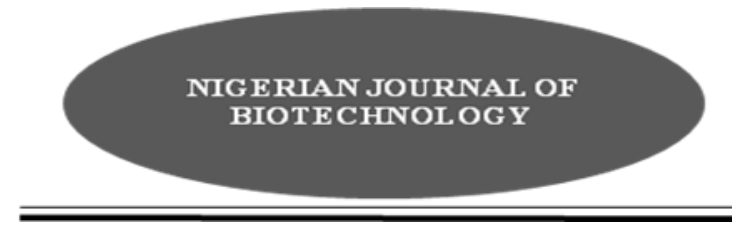

\title{
Co-production of parasporal crystal toxins and antimicrobial substances by Bacillus thuringiensis BAR 3
}

\author{
Chuka-Ogwude, D., Nwuche, C. O. and Ogbonna, J. C. \\ Department of Microbiology, University of Nigeria, Nsukka, Nigeria.
}

\begin{abstract}
(Received: 09:02:2017; Accepted: 05:03:2017)
Abstract

Co-production of antimicrobial substances and insecticidal compounds by Bacillus thuringiensis BAR 3 was investigated. The cell free supernatant (CFS) of B. thuringiensis showed inhibitory activities against both Gram positive (B. thuringiensis IF013866 and Staphylococcus aureus ATCC 25923) and Gram negative (Proteus mirabilis ATCC 29906) bacteria. Proteus mirabilis ATCC 29906 was the most sensitive to the CFS and the inhibition zone diameter was $10.10 \mathrm{~mm}$. Maximum production of both the endotoxin and antimicrobial substances were achieved when the basal medium ( $3 \mathrm{~g} / \mathrm{L}$ beef extract, $5 \mathrm{~g} / \mathrm{L}$ peptone and $8 \mathrm{~g} / \mathrm{L} \mathrm{NaCl}$ ) was supplemented with $10 \mathrm{~g} / \mathrm{L}$ glucose, $3 \mathrm{~g} / \mathrm{L}$ yeast extract, $2 \mathrm{~g} / \mathrm{L} \mathrm{KH}_{2} \mathrm{PO}_{4}, 1 \mathrm{~g} / \mathrm{L}$ $\mathrm{MgSO}_{4}$, at $\mathrm{pH}$ of 7 . The antimicrobial activity of the CFS was stable over a wide range of $\mathrm{pH}$ $(2-8)$ and temperature $\left(30-100^{\circ} \mathrm{C}\right)$ but the activity was completely lost after autoclaving for $15 \mathrm{~min}$ at $121^{\circ} \mathrm{C}$. The antimicrobial activity was unaffected by amylase and catalase but was nearly completely denatured by protease and proteinase $K$. Under the optimum culture condition, the total Bacillius thuringiensis cell count was $1.30 \times 10^{12}(\mathrm{cfu} / \mathrm{ml})$ with $97 \%$ sporulation (spore count was $1.26 \times 10^{12} \mathrm{cfu} / \mathrm{ml}$ ) and the $L_{50}$ was $0.096 \mathrm{mg} / \mathrm{L}$ against third instar larvar of Culex pipens.
\end{abstract}

Keywords: Bio-insecticide, anti-microbial substances, Bacillus thuringiensis, endotoxin, sporulation. Correspondence: james.ogbonna@unn.edu.ng

\section{Introduction}

Over the years, the use of chemicals in the control of insects, pests and vectors has developed as an acceptable practice without much consideration to the apparent ecological consequences. The large scale and widespread use of chemical insecticides is due mainly to their rapid kill and broad spectrum toxicity (Ozgur et. al., 2005). However, due to the potentially long shelf life of many of the preparations and the tendency of the toxic residues to accumulate in soil, water and food, coupled with their non-selective property and widely reported cases of insect resistance (Kumar, 2008), the search for a more sensitive and environmentally acceptable insecticidal formulation has become very imperative. Long term exposure to several of the chemicals causes cancer, liver damage, immunotoxicity, birth defects and reproductive problems in both man and animals (Kouser and Qaim, 2011).

Some microorganisms produce biological agents capable of causing morbidity and mortality of other organisms including insects. Early studies on the performance of several microbial bioactive preparations indicate a narrow host range and sensitivity towards pollinating insects and vertebrates. The application of this class of microorganisms to control insects and pests represents an approach that is safe, effective and environmentally sustainable. In fact, viruses, fungi, protozoa and bacteria have been used as biological pest control agents. Presently, the bacterium Bacillus thuringiensis is the most popular microorganism due to its widely acknowledged entomopathogenic potential against several insect orders (Palma et. al., 
2014). The organism is ubiquitous, Grampositive and spore-forming and produces insecticidal crystal proteins during sporulation (Bravo et. al., 2011; Siegwart et. al., 2015) as well as during the vegetative growth (Palma et. al., 2014). The toxic activity of the proteins produced by its plasmid encoded cry genes varies with insect type and mutation can lead to development of resistance (Tay et. al., 2015). Some strains of this bacterium have been used for nearly 50 years, as an alternative to chemical pesticides without reports of undesirable side effects (Ozgur et. al., 2005). Unfortunately, one of the major shortcomings plaguing the widespread use of microbial based insecticide today is the high cost of production.

Members of the Bacillus group are also good producers of antimicrobial substances, including peptide, lipopeptide antibiotics and bacteriocins (Stein, 2005). The production of antimicrobial substances and sporulation capacity confer Bacillus strains with a double advantage in terms of their survival in different habitats. $B$. thuringiensis has profound use both as an insecticidal agent in the form of parasporal crystal toxins and as a microbicide in the form of bacteriocins. Bacteriocins produced by $B$. thuringiensis have been well studied and some of them are presently in use (Paik et. al., 1997; Cherif et. al., 2001).

The antimicrobial substances produced by $B$. thuringiensis are extracellular while the parasporal crystals are intra cellular, thereby making their co-production a viable method of reducing the cost of production. In other words, after the cultivation, the bio-insecticide is recovered as the cell biomass while the antimicrobial substances are recovered from the culture filtrate. The aim of this study is, therefore, to optimize culture conditions for simultaneous production of insecticidal crystal endotoxins and antimicrobial products by $B$. thuringiensis.

\section{Materials and Methods}

\section{Microorganism and seed culture}

The Bacillus thuringiensis BAR 3 strain used in this study was isolated from bamboo in Nsukka, Nigeria (Obeta and Okafor, 1984) and maintained on nutrient agar slants at $4^{\circ} \mathrm{C}$ in the Department of Microbiology, University of Nigeria, Nsukka. They are sub-cultured every month. In this study, the organism was reactivated by inoculating a loopful of culture from the slant into a $50 \mathrm{~mL}$ of nutrient broth in a 250 $\mathrm{mL}$ Erlenmeyer flask. The flask was incubated at $30 \pm 2^{\circ} \mathrm{C}$ for $72 \mathrm{~h}$. The culture broth was diluted to an optical density of $0.3 \mathrm{OD}_{600}$ and $1.0 \mathrm{~mL}$ of the diluents, corresponding to $1.5 \times 10^{7} \mathrm{cfu}$ was used as standard inoculum.

\section{Cultivation and optimization experiments}

For all the cultivation experiments, 1.0 $\mathrm{mL}$ of pre- culture $\left(1.5 \times 10^{7} \mathrm{cfu}\right)$ was inoculated into $100 \mathrm{~mL}$ of medium in $250 \mathrm{~mL}$ Erlenmeyer flasks. The flasks were incubated at room temperature with constant agitation at 160 rpm for $120 \mathrm{~h}$. Nutrient broth composed of beef extract, $3 \mathrm{~g} / \mathrm{L}$; peptone, $5 \mathrm{~g} / \mathrm{L}$ and $\mathrm{NaCl}, 8 \mathrm{~g} / \mathrm{L}$ was selected for use as the culture medium having performed better than Luria Bertani (yeast extract, $5 \mathrm{~g} / \mathrm{L}$; peptone, $10 \mathrm{~g} / \mathrm{L}$ ) in supporting higher growth and metabolite production by $B$. thuringiensis in preliminary experiments. For the optimization experiments, the method adopted was to optimize one factor at a time and then use the optimum value in the next optimization step.

\section{Effect of glucose concentrations}

Different glucose concentrations $(5,10$, $15,20,25 \mathrm{~g} / \mathrm{L}$ ) were added to the basal medium (nutrient broth) to evaluate its effect as carbon source on key performance indices (growth, sporulation, antibacterial production and mosquitocidal toxin production) by Bacillus thuringiensis. Cell growth was monitored by both spectrophotometry $(600 \mathrm{~nm})$ and plate count assays every $24 \mathrm{~h}$. At the end of each phase of cultivation $(120 \mathrm{~h})$, serial decimal dilutions of the final whole culture were made in sterile water and $1 \mathrm{~mL}$ of the dilutions was added to $15 \mathrm{~mL}$ molten agar at $45^{\circ} \mathrm{C}$. Plates were incubated at room temperature $\left(30 \pm 2^{\circ} \mathrm{C}\right)$ and the number of colonies counted after 24 or $48 \mathrm{~h}$. For the viable spore counts, cultures were maintained at $65^{\circ} \mathrm{C}$ for 20 min before plating as described above (Obeta and Okafor, 1984).

\section{Effect of nutrient supplementation}

The effects of adding varying concentrations $(1 \mathrm{~g} / \mathrm{L}-5 \mathrm{~g} / \mathrm{L})$ of yeast extracts, $\mathrm{KH}_{2} \mathrm{PO}_{4}$ and $\mathrm{MgSO}_{4}$ on cell growth, sporulation, antibacterial substances production and mosquitocidal toxin production by Bacillus thuringiensis were investigated one at a time. 
The optimum concentration of one nutrient was fixed for the subsequent experiment.

\section{Effect of $\mathrm{pH}$}

The effect of $\mathrm{pH}$ on the growth and productivity of $B$. thuringiensis was investigated by altering the initial $\mathrm{pH}$ of the basal medium between 5 and 9. The $\mathrm{pH}$ was adjusted using $1.0 \mathrm{M}$ solution of hydrochloric acid $(\mathrm{HCl})$ or 1.0 $M$ solution of sodium hydroxide $(\mathrm{NaOH})$. The cultures were incubated for $120 \mathrm{~h}$ but samples were taken every day for analysis.

\section{Bioassay of $B$. thuringiensis powder against mosquito larvae}

The B. thuringiensis powder was obtained by acetone co-precipitation (Dulmage, 1970). The pH of the broth was first adjusted to 7 after which it was centrifuged in batches at $5000 \mathrm{rpm}$. The supernatant was separated and used for agar well diffusion assay against some target microorganisms while the sediment was suspended in $1 / 10$ volume $(10 \mathrm{~mL}) 4 \%$ lactose and mixed with a magnetic stirrer for 20 minutes. During the stirring, $40 \mathrm{~mL}$ of acetone was slowly added to the mixture and stirred for a further $30 \mathrm{~min}$. After stirring, the mixture was allowed to stand for $10 \mathrm{~min}$ and then filtered through a suction pump.

The residue was washed twice with 20 $\mathrm{mL}$ of acetone and again filtered before allowing to dry overnight. Spore crystals from each stage of the experiment were assayed against third instar larvae of laboratory reared Culex pipiens. Powder suspensions of the crystal spores were prepared by mixing $100 \mathrm{mg}$ of the powder into 1 litre of distilled water. Two fold serial dilutions of the suspension ( 1 through $0.0625 \mathrm{mg} / \mathrm{L}$ ) were made in distilled water then 20 larvae were added to $100 \mathrm{~mL}$ of each dilution and were observed for mortality after 24 and $48 \mathrm{~h}$. LC 50 values were recorded for each concentration as concentrations that caused $50 \%$ mortality of the larvae in the cups. Larvae were considered dead if they did not move when touched with a blunt needle. An extra cup containing 20 larvae in distilled water was used as control. Any mortality in the control was corrected with the Abbott formula (Abbott, 1925).

\section{Selection of indicator organisms \\ Cell free supernatant (CFS) of $B$.} thuringiensis BAR 3 broth culture was assayed against five Gram positive (Bacillus cereus ATCC
10987, B. thuringiensis IFO13866, Lactobacillus sp. ATCC 11146, Staphylococcus aureus ATCC 25923 and Listeria monocytogenes ATCC 35152) and two Gram negative bacteria (Escherichia coli ATCC 11105 and Proteus mirabilis ATCC 29906) obtained from the stock cultures maintained in the Department of Microbiology, University of Nigeria, Nsukka.

\section{Bioassay for antimicrobial activity}

The presence of antimicrobial agents in the culture medium was tested by a modification of the agar well diffusion method proposed by Tag and McGiven (1971). Cell free supernatant (CFS) was collected by centrifugation $(5,000 \mathrm{~g} /$ $30 \mathrm{~min}, 4^{\circ} \mathrm{C}$ ) of the culture broth and sterilized by filtering through Millex (Millipore) GV $0.22 \mu \mathrm{m}$ filters. Petri dishes were filled with nutrient agar to a $5 \mathrm{~mm}$ thickness and allowed to solidify. The nutrient agar plates were then seeded by spreading $0.1 \mathrm{ml}$ of a $24 \mathrm{~h}$ culture broth of the indicator microorganisms diluted to $3.0 \times 10^{8}$ $\mathrm{cfu} / \mathrm{ml}$. Wells were then made on the surface with a $4 \mathrm{~mm}$ cork borer. The $\mathrm{pH}$ of the CFS was adjusted to 7 and $0.3 \mathrm{~mL}$ of the CFS preparation was added to each well. The inoculated plates were stored at $4^{\circ} \mathrm{C}$ for $24 \mathrm{~h}$ to allow for diffusion of the antibacterial compounds into the agar.

The inoculated plates were then incubated at $30 \pm 2^{\circ} \mathrm{C}$ for $24 \mathrm{~h}$ for the growth of the indicator organisms. Zones of clearing due to the activity of the antibacterial agents in the wells were measured by taking the averages of three cross sections of the zones less $4 \mathrm{~mm}$ (the diameter of the cork borer). Un-inoculated medium was also used as control.

\section{Thermal and $\mathrm{pH}$ stability of the antimicrobial agent \\ To study the thermostability of the} antimicrobial agent, a $5 \mathrm{~mL}$ aliquot of sterile CFS obtained after the last optimization stage was incubated for $15 \mathrm{~min}$ at various temperatures ( $30{ }^{\circ} \mathrm{C}$ to $100{ }^{\circ} \mathrm{C}$ with 10 degree increments). An aliquot was also autoclaved at $121^{\circ} \mathrm{C}, 15 \mathrm{psi}$ for 15 min. Following heat treatment, samples were cooled to room temperature and residual activities were compared with those of the untreated (control) samples by agar well diffusion. To study the effect of $\mathrm{pH}$ on antimicrobial activity, the $\mathrm{pH}$ of the CFS was adjusted in steps of one $\mathrm{pH}$ unit from 1 to 12 using either $1 \mathrm{M} \mathrm{HCl}$ or $1 \mathrm{M} \mathrm{NaOH}$ as required. After $\mathrm{pH}$ adjustment, the CFS was incubated for 
$1 \mathrm{~h}$ at $30^{\circ} \mathrm{C}$ and the antibacterial activities were determined by the agar well diffusion method.

\section{Effect of enzyme}

Effects of some enzymes on the antimicrobial compounds were investigated by treating the CFS aliquots with Proteinase $\mathrm{K}$ (from Tritirachium album, Sigma no. P-2308), Protease (from Streptomyces griseus, Sigma no. P-6911), a-amylase (from barley malt VIII-A, Sigma no. A-2771) and catalase (from Corynebacterium glutamicum, Sigma no. 02071). Following enzymatic treatment, the CFS was tested for antimicrobial activity.

The enzyme working buffer solutions, $\mathrm{pH}$ and temperature conditions were as follows: Proteinase $\mathrm{K}$-buffer $(100 \mathrm{~mol} / \mathrm{L}$ Tris-HCL), $\mathrm{pH}$ 7.5 at $20^{\circ} \mathrm{C}$; Protease-buffer $(0.04 \mathrm{~mol} / \mathrm{L}$ potassium phosphate), $\mathrm{pH} 7.5$ at $20^{\circ} \mathrm{C}$; aamylase-buffer $(0.02 \mathrm{~mol} / \mathrm{L}$ sodium phosphate (monobasic) plus $0.06 \mathrm{~mol} / \mathrm{L} \mathrm{NaCI}$ ), $\mathrm{pH} 7$ at $20^{\circ} \mathrm{C}$; Catalase - $0.05 \mathrm{~mol} / \mathrm{L}$ potassium phosphate (monobasic), pH 7.0 at $20^{\circ} \mathrm{C}$. For proteinase $\mathrm{K}$, protease and a-amylase enzymes were added to final concentrations of $1 \mathrm{mg} / \mathrm{mL}$ CFS. Catalase was added at 40,000 U/mL CFS (Gray et. al., 2006).

All the solutions were filter sterilized through Millex (Millipore) GV $0.22 \mu \mathrm{m}$ filters and then added to supernatants. Samples were incubated for $120 \mathrm{~min}$ at $37^{\circ} \mathrm{C}$, and then heated to $100^{\circ} \mathrm{C}$ for $2 \mathrm{~min}$ for enzyme inactivation. Controls consisted of CFS and the corresponding enzyme buffer. Any remaining antimicrobial activity in the treated CFS was determined by agar well diffusion as described before. Glucose concentration in the medium was estimated by the Dinitrosalicylic Acid (DNS) method of Miller (1972).

\section{Expression of growth rates and spore yields}

The amount of spores obtained per gram glucose was calculated from the maximum spore concentration attained and the total amount of glucose consumed during the cultivation as expressed in Equation 1.

$Y_{x / s}=\left\{\left(X_{\max }-X_{i}\right) /\left(S_{i}-S_{0}\right)\right\}-Y_{n}$

Where $X_{i}$ is the initial spore concentration (spores/L), $X_{\max }$ is the final spore concentration (spores/L), $S_{i}$ is the initial glucose concentration $(\mathrm{g} / \mathrm{L})$ and $\mathrm{S}_{0}$ is the residual glucose concentration at the end of the cultivation $(\mathrm{g} / \mathrm{L})$.
$Y_{n}$ is the yield from organic sources in the basal medium obtained by cultivating the cells in medium without any glucose and calculated as shown in Equation 2.

$\mathrm{Y}_{\mathrm{n}}=\left(\mathrm{X}_{\max }-\mathrm{X}_{\mathrm{i}}\right) / \mathrm{N}$

Where $\mathrm{N}$ is the concentration of organic nitrogen in the medium in $\mathrm{g} / \mathrm{L}$

The cell growth rates $\left(P_{s}\right)$ (cfu/L.h), were expressed as shown in Equation 3;

$\mathrm{P}_{\mathrm{s}}=\left(\mathrm{X}_{\max }-\mathrm{X}_{0}\right) / \mathrm{t}$

Where $X_{\max }$ is the cell concentration at $24 \mathrm{~h}$ and $X_{0}$ is the initial cell concentration at zero $h$. ' $t$ ' is the cultivation time(24 h).

Abbott's formula was used to correct any mortality observed in the control for the bioassay of $B$. thuringiensis powder against mosquito larvae. The corrected mortality was obtained thus:

$\mathrm{C}=\{1-(n$ in T after treatment / $\mathrm{n}$ in Co after treatment) $\} \times \mathrm{N}$

Where $C$ is corrected larvae population, ' $n$ ' is final larvae population, $T$ is treated water, $C o$ is control water and $\mathrm{N}$ is initial larva population.

\section{Statistical analysis}

All the experiments were performed in triplicates and the effects of the various culture conditions were determined by one way analysis of variance (ANOVA). Where significant differences were observed, the means were separated by the Least Significant Difference (LSD). Statistical analysis was carried out using IBM SPSS software version 20.

\section{Results and Discussion}

\section{Selection of indicator organism}

Table 1 shows the susceptibility patterns of various indicator organisms to the antibacterial substances in the $B$. thuringiensis BAR3 culture broth. Of the organisms evaluated, S. aureus and Proteus spp. showed visible zones of inhibition when challenged with the cell free supernatant (CFS) of the culture broth. The diameter of the zone of inhibition obtained with S. aureus was $1.87 \mathrm{~mm}$ while with Proteus spp, it was $2.11 \mathrm{~mm}$. Proteus $s p p$ was therefore selected as the test organism for the subsequent 
experiments. After optimization, the inhibition zone diameters increased to 3.8 and 10.0 for $S$. aureus and Proteus spp. respectively. Furthermore, B. thuringiensis IFO13866 which was not inhibited by CFS from the basal medium showed IZD of $1.28 \mathrm{~mm}$ when challenged with CFS from the optimized culture broth. Bacteriocins have shown to be very effective in the control of food spoilage organisms (FuenteSalsido et. al., 2008) as well as pathogenic bacteria especially the multi-drug resistant strains of $S$. aureus and Pseudomonas aeruginosa leading to significant reduction in the high hospital costs and mortality associated with their dissemination (Abriouel et al., 2011).

\section{Effect of glucose supplementation on growth characteristics of $B$. thuringiensis}

Growth of $B$. thuringiensis was significantly promoted by addition of glucose to the basal medium (Table 2). Cell growth increased with increase in glucose concentration in the medium until reaching the highest cell concentration of $1.17 \times 10^{12} \mathrm{cfu} / \mathrm{mL}$ at $25 \mathrm{~g} / \mathrm{L}$ glucose. This compares with a cell concentration of $6.39 \times 10^{11}$ $\mathrm{cfu} / \mathrm{mL}$ obtained with the basal medium without glucose. However, addition of glucose beyond $15 \mathrm{~g} / \mathrm{L}$ did not result in a proportional increase in both cell growth and sporulation. Production of both antimicrobial substances and crystal toxins were highest with the medium supplemented with $10 \mathrm{~g} / \mathrm{L}$ of glucose.

Glucose has been identified as the most utilized source of carbon for $B$. thuringiensis (Sarrafzadeh, 2012), but Anderson and Jayaraman (2003) reported potential inhibitory effects when critical glucose level is exceeded. At the end of cultivation, cultures grown in media supplemented with 0,5 and $10 \mathrm{~g} / \mathrm{L}$ glucose attained well over $90 \%$ sporulation corresponding to viable spore counts of $6.35 \times 10^{11}, 7.77 \times 10^{11}$ and $8.1 \times 10^{11}$ spore $/ \mathrm{ml}$ respectively while those grown in media with 15 , 20 and $25 \mathrm{~g} / \mathrm{L}$ glucose reached 75,59 , and $56 \%$ sporulation levels corresponding to $8.06 \times 10^{11}$, $6.85 \times 10^{11}$ and $6.52 \times 10^{11}$ spores $/ \mathrm{mL}$ respectively. Growth rate increased with increasing concentrations of glucose up till 25 $\mathrm{g} / \mathrm{L}$, with a final value of $4.91 \times 10^{10} \mathrm{cfu} / \mathrm{L}$.h.

Agar well diffusion assays performed with CFS obtained from media containing 0,5 and 10 $\mathrm{g} / \mathrm{L}$ glucose gave inhibition zone diameters (IZD) values of $2.1,2.11$ and $2.1 \mathrm{~mm}$, respectively against the indicator organism. CFS from samples containing 15, 20 and $25 \mathrm{~g} / \mathrm{L}$ glucose showed no visible zone of inhibition indicating no improvement on the production of antimicrobial agents with further addition of glucose. Paralysis was observed among the mosquito larvae within $8 \mathrm{~h}$ of administering $1 \mathrm{mg} / \mathrm{L}$ of bacterial spore powder at all glucose concentrations tested. The $\mathrm{LC}_{50}$ of the larvae measured after $48 \mathrm{~h}$ exposure is also presented in Table 2. The highest toxicity to $P$. culex was $0.268 \mathrm{mg} / \mathrm{L}$ from $10 \mathrm{~g} / \mathrm{L}$ glucose augmentation while the least toxicity was observed in the medium supplemented with $25 \mathrm{~g} / \mathrm{L}$ glucose $(0.335 \mathrm{mg} / \mathrm{L})$. Glucose concentration of $10 \mathrm{~g} / \mathrm{L}$ was selected as the optimum concentration for antimicrobial and parasporal crystal production and was thus adopted for the subsequent experiments.

Effect of yeast extract on growth, antimicrobial and parasporal crystal production by $B$. thuringiensis

Addition of yeast extract (up to $3 \mathrm{~g} / \mathrm{L}$ ) to the basal medium had negligible effects on the growth and sporulation of $B$. thuringiensis (Table 3). However, addition of higher concentrations (4 and $5 \mathrm{~g} / \mathrm{L}$ ) of yeast extract resulted in decrease in cell concentration. Although Sarrafzadeh (2012) also reported insignificant response of Bacillus thuringiensis to yeast extract, other studies (Anderson and Jayaraman , 2003; Zeinat et al., 2008) have shown that yeast extract is a growth promoter.

The highest growth rate $\left(3.75 \times 10^{10}\right.$ cfu/L.h ) was observed in a medium containing $1 \mathrm{~g} / \mathrm{L}$ yeast extract. Increasing concentrations of yeast extract resulted in decreased growth rate and the lowest value $\left(3.37 \times 10^{10} \mathrm{cfu} /\right.$ L.h $)$ was obtained in a medium containing $5 \mathrm{~g} / \mathrm{L}$ yeast extract. Although increasing concentration of yeast extract resulted in decrease in the number of viable spores, the effect was not significant. More than $90 \%$ sporulation was observed by the end of cultivation in all the yeast extract concentrations tested in this study.

The antimicrobial activity of the CFS was increased by the addition of yeast extract. The inhibition zone diameter of the control system (containing $0 \mathrm{~g} / \mathrm{L}$ yeast extract) was $2.1 \mathrm{~mm}$. This increased to 4.15 and $5.95 \mathrm{~mm}$ in the CFS obtained from media supplemented with 1 and 2 $\mathrm{g}$ of yeast extract respectively. The highest IZD 
(8.05 $\mathrm{mm}$ ) was produced by cultures grown in medium containing $3 \mathrm{~g} / \mathrm{L}$ yeast extract. Further increase $(4 \mathrm{~g} / \mathrm{L})$, in yeast concentration resulted in significant decline in IZD $(4.04 \mathrm{~mm})$ with the least $(3.03 \mathrm{~mm})$ occurring at $5 \mathrm{~g} / \mathrm{L}$. The positive influence of yeast extract on the production of antimicrobial substances is thought to be principally due to increased levels of amino acids available for the production of enzymes essential for its production. Thus the yeast extract was beneficial to the formation of antimicrobial substances but not for cell growth. Toxicity $\left(L C_{50}\right)$ of the mosquitocidal toxin increased on addition of yeast extract (from 1 to $3 \mathrm{~g} / \mathrm{L}$ ), with a maximum toxicity of $\left(\mathrm{LC}_{50}=0.21 \mathrm{mg} / \mathrm{L}\right)$ at 3 $\mathrm{g} / \mathrm{L}$ yeast extract supplementation.

However further increase in concentration of yeast extract produced lower toxicity with the least toxicity ( LC50 $=0.288$ $\mathrm{mg} / \mathrm{L}$ ) occurring in the medium augmented with $5 \mathrm{~g} / \mathrm{L}$ yeast extract. The concentration of $3 \mathrm{~g} / \mathrm{L}$ yeast extract was selected and adopted for the next stage of optimization.

\section{Effect of $\mathrm{KH}_{2} \mathrm{PO}_{4}$ on growth characteristics of $\mathrm{B}$. thuringiensis}

The addition of $2 \mathrm{~g} / \mathrm{L}$ of $\mathrm{KH}_{2} \mathrm{PO}_{4}$ to the basal medium significantly increased the viable cell count of $B$. thuringiensis (Table 4). However, increasing the concentration of $\mathrm{KH}_{2} \mathrm{PO}_{4}$ above $2 \mathrm{~g} / \mathrm{L}$ did not improve the growth of the organism; rather it led to a decrease in count. The lowest cell count of $7.83 \times 10^{11}$ was achieved at $5 \mathrm{~g} / \mathrm{L} \quad \mathrm{KH}_{2} \mathrm{PO}_{4}$ concentration as compared to $1.13 \times 10^{12}$ obtained with a medium containing $2 \mathrm{~g} / \mathrm{L}$ of $\mathrm{KH}_{2} \mathrm{PO}_{4}$. Addition of $\mathrm{KH}_{2} \mathrm{PO}_{4}$ up to $2 \mathrm{~g} / \mathrm{L}$ also had a positive effect on the growth rate of the organism. The beneficial effect of $\mathrm{KH}_{2} \mathrm{PO}_{4}$ on the growth of the organism could be attributed to the improvement in the buffering capacity of the medium or due to the effects of potassium and phosphorus assimilation on enzyme activities and metabolic activities.

By the end of cultivation, the percentage sporulation had attained above $90 \%$ with the viable spore count of $1.11 \times 10^{12}$ spores $/ \mathrm{mL}$ in culture supplemented with $2 \mathrm{~g} / \mathrm{L}$ $\mathrm{KH}_{2} \mathrm{PO}_{4}$. However, when $\mathrm{KH}_{2} \mathrm{PO}_{4}$ concentration was increased to $5 \mathrm{~g} / \mathrm{L}$, sporulation was delayed resulting in a low spore concentration of $7.61 \mathrm{x}$ $10^{11}$ spores $/ \mathrm{mL}$. $\mathrm{KH}_{2} \mathrm{PO}_{4}$ supplementation also increased the antimicrobial activities of the CFS, resulting in IZD of $10.05 \mathrm{~mm}$ at $2 \mathrm{~g} / \mathrm{L} \mathrm{KH}_{2} \mathrm{PO}_{4}$. Further increase in the concentration of $\mathrm{KH}_{2} \mathrm{PO}_{4}$ did not result in significant increase in the antimicrobial activities. Supplementation of $\mathrm{KH}_{2} \mathrm{PO}_{4}$ to the medium also had positive effect on production of parasporal crystal toxin. The $\mathrm{LC}_{50}$ on $C$. pipens larvae was $0.115 \mathrm{mg} / \mathrm{L}$ in culture containing $2 \mathrm{~g} / \mathrm{L} \quad \mathrm{KH}_{2} \mathrm{PO}_{4}$. However, higher concentration of $\mathrm{KH}_{2} \mathrm{PO}_{4}$ reduced parasporal crystal toxin production. The $\mathrm{LC}_{50}$ increased to $0.256 \mathrm{mg} / \mathrm{L}$ in a culture containing $5 \mathrm{~g} / \mathrm{L} \mathrm{KH_{2 }} \mathrm{PO}_{4}$. In summary, addition of low concentration of $\mathrm{KH}_{2} \mathrm{PO}_{4}(<2 \mathrm{~g} / \mathrm{L})$ promoted cell growth, and production of both endotoxin and antimicrobial substances by $B$. thuringiensis. Zhong et al., (2013) reported a significantly positive effect of $\mathrm{KH}_{2} \mathrm{PO}_{4}$ on the production of bacteriocin-like substances by $B$. cereus.

\section{Effect of $\mathrm{MgSO}_{4}$ on growth characteristics of $\mathrm{B}$. thuringiensis}

Table 5 shows the effect of varying concentrations of $\mathrm{MgSO}_{4}$ on $\mathrm{B}$. thuringiensis BAR3. There was no change in the viable cell counts on account of the addition of $\mathrm{MgSO}_{4}$. The effects of $\mathrm{MgSO}_{4}$ on the production of both antimicrobial agents and crystal toxins were also negligible. At the end of the fermentation, all the cultures had above $90 \%$ sporulation. Higher concentrations of $\mathrm{MgSO}_{4}$ yielded slightly lower spore counts with $5 \mathrm{~g} / \mathrm{L} \mathrm{MgSO}_{4}$ producing the least number of $9.29 \times 10^{11}$ spores $/ \mathrm{mL}$. The addition of $\mathrm{MgSO}_{4}$ had no impact on the production of antimicrobial agents. Agar well diffusion assays performed with CFS of the cultures showed no significant variation in the IZD. The effect of $\mathrm{MgSO}_{4}$ on the parasporal crystal was also not significant as shown in table 5. In all the cultures, the $\mathrm{LC}_{50}$ against $C$. pipiens ranged between 0.100 and $0.115 \mathrm{mg} / \mathrm{L}$, except at high concentration of $5 \mathrm{~g} / \mathrm{L} \mathrm{MgSO}_{4}$ where the $\mathrm{LC}_{50}$ was $0.23 \mathrm{mg} / \mathrm{L}$.

Effect of $\mathrm{pH}$ on growth characteristics of $B$. thuringiensis

The effect of the initial $\mathrm{pH}$ on key growth indices of $B$. thuringiensis is shown in table 6 . Cell growth improved slightly as $\mathrm{pH}$ increased from 5 to 7 reaching the highest cell count of $1.30 \times 10^{12} \mathrm{cfu} / \mathrm{mL}$ at $\mathrm{pH}$ 7. Increasing the $\mathrm{pH}$ above 7 resulted in lower counts with $\mathrm{pH}$ 9 having the least counts of $1.09 \times 10^{12} \mathrm{cfu} / \mathrm{mL}$. Growth rate followed similar order and increased progressively to $6.12 \times 10^{10} \mathrm{cfu} / \mathrm{L}$.h at $\mathrm{pH} 7$. 
Beyond $\mathrm{pH} 7$, the growth rate declined gradually to $5.45 \times 10^{10} \mathrm{cfu} / \mathrm{L}$.h at $\mathrm{pH}$ 9. Obeta and Okafor (1984) had reported a $\mathrm{pH}$ of 7.5 for optimum growth and production of crystal toxins. At the end of the cultivation period, the cells had entered into the stationary phase and over $90 \%$ sporulation with maximum viable spore counts of $1.26 \times 10^{12}$ spores $/ \mathrm{mL}$ at $\mathrm{pH} 7$.

There were no significant differences in the IZD over the $\mathrm{pH}$ range of $5-9$. Furthermore, the effect of $\mathrm{pH}$ on production of parasporal crystal was not significant. Although the highest toxicity to $C$. pipiens occurred at $\mathrm{pH}$ 7 with $\mathrm{LC}_{50}$ value of $0.096 \mathrm{mg} / \mathrm{L}$, the LC50 obtained at other $\mathrm{pH}$ values were comparable $(0.101-0.11 \mathrm{gm} / \mathrm{L})$.

Temperature stability of the antimicrobial substances produced by $B$. thuringiensis

The effect of temperature on the antimicrobial activity of CFS from the optimized medium is shown in Figure 1 . The heat treatment of the CFS for 15 min over a temperature range of 30 to $100^{\circ} \mathrm{C}$, had no significant effect on antimicrobial activity. However, autoclaving the CSF at $121^{\circ} \mathrm{C}$ for 15 min resulted in total loss of activity. The stability of the CFS to temperature implies that the compounds may belong to class II bacteriocins known as non-lantibiotics.

Effects of enzymes on antimicrobial activity of the CFS

The effects of some enzymes on antimicrobial activity of the cell free supernatants are shown in figure 2. There was a significant loss of antimicrobial activity after treatment with protease and proteinase $\mathrm{K}$. However, no loss in activity was observed when the CFS was incubated with a-amylase and catalase. The result strongly suggests that the antimicrobial principle in the CFS was of a protein nature. Similar results were reported for B. thuringiensis B439 by Ahern et. al., (2003).

The above results have demonstrated that Bacillus thuringiensis is capable to simultaneous production of both insecticidal and antimicrobial substances in submerged cultures. The mechanisms of action of Bacillus thurnigiensis endotoxin have been extensively studied (Sunemann et al., 2014) and the hostspecificity has developed as an adaptation to human-generated ecological niches (Argolo-Filho and Loguercio, 2014).

\section{Conclusion}

A method for the production of insecticidal endotoxins and antimicrobial products of $B$. thuringiensis was investigated in a simple batch process. The results show that Bacillus thuringiensis can co-produce both the insecticidal endotoxins and antimicrobial substances. Thus, after cultivation, the parasporal crystal is separated while the antimicrobial substances can be recovered from the cell free supernatant. This will definitely reduce the overall cost of production of the two products. 
Table 1: Antibacterial profile of cell free supernatant (CFS) of B. thuringiensis BAR 3 by the agar well diffusion before and after optimization

\begin{tabular}{lccc}
\hline Indicator organism & Incubation temperature $\left({ }^{0} \mathrm{C}\right)$ & \multicolumn{2}{l}{ Inhibition zone diameter $(\mathrm{mm})$} \\
\hline B. cereus ATCC10987 & 30 & Before & After \\
B. thuringiensis IFO13866 & 30 & $\mathrm{Nvz}$ & $\mathrm{Nvs}$ \\
Lactobacillus sp ATCC 11146 & 37 & $\mathrm{Nvz}$ & 1.28 \\
S. aureus ATCC 25923 & 37 & $\mathrm{Nvz}$ & $\mathrm{Nvz}$ \\
L. monocytogenes ATCC 35152 & 37 & 1.87 & 3.80 \\
Escherichia coli ATCC 11105 & 37 & $\mathrm{Nvz}$ & $\mathrm{Nvz}$ \\
Proteus mirabilis ATCC 29906 & 37 & $\mathrm{Nvz}$ & $\mathrm{Nvz}$ \\
\hline
\end{tabular}

nvs: no visible zone

Table 2: Effect of different glucose concentrations on growth characteristics of $B$. thuringiensis

\begin{tabular}{lllllll}
\hline $\begin{array}{l}\text { Glucose } \\
\text { Conc. }(\mathrm{g} / \mathrm{L})\end{array}$ & $\begin{array}{l}\text { Viable Cell } \\
\text { Count } \\
(\mathrm{cfu} / \mathrm{mL})\end{array}$ & $\begin{array}{l}\text { Viable } \\
\text { Spores } \\
\text { Count } \\
(\mathrm{cfu} / \mathrm{mL})\end{array}$ & $\begin{array}{l}\text { Sporulation } \\
(\%)\end{array}$ & $\begin{array}{l}\text { Inhibition } \\
\text { Zone } \\
\text { Diameter } \\
(\mathrm{mm})\end{array}$ & $\begin{array}{l}\mathrm{LC}_{50} \\
(\mathrm{mg} / \mathrm{L})\end{array}$ & $\begin{array}{l}\text { Growth } \\
\text { Rate } \\
(\mathrm{cfu} / \mathrm{L} . \mathrm{h})\end{array}$ \\
\hline 0 & $6.39 \times 10^{11}$ & $6.35 \times 10^{11}$ & 99 & 2.10 & 0.28 & $3.02 \times 10^{10}$ \\
5 & $7.79 \times 10^{11}$ & $7.77 \times 10^{11}$ & 99 & 2.11 & 0.274 & $3.24 \times 10^{10}$ \\
10 & $8.30 \times 10^{11}$ & $8.10 \times 10^{11}$ & 97 & 2.10 & 0.268 & $3.72 \times 10^{10}$ \\
15 & $1.08 \times 10^{12}$ & $8.06 \times 10^{11}$ & 75 & 0.00 & 0.295 & $4.54 \times 10^{10}$ \\
20 & $1.16 \times 10^{12}$ & $6.85 \times 10^{11}$ & 59 & 0.00 & 0.309 & $4.83 \times 10^{10}$ \\
25 & $1.17 \times 10^{12}$ & $6.52 \times 10^{11}$ & 56 & 0.00 & 0.335 & $4.91 \times 10^{10}$ \\
\hline
\end{tabular}

Note: The basal medium was composed of beef extract, $3 \mathrm{~g} / \mathrm{L}$; peptone, $5 \mathrm{~g} / \mathrm{L}$ and $\mathrm{NaCl}, 8 \mathrm{~g} / \mathrm{L}$ 
Table 3: Effect of different concentration of yeast extract on growth characteristics of $B$. thuringiensis

\begin{tabular}{lllllll}
\hline $\begin{array}{l}\text { Conc. of } \\
\text { yeast } \\
\begin{array}{l}\text { extract } \\
(\mathrm{g} / \mathrm{L})\end{array}\end{array}$ & $\begin{array}{l}\text { Viable cell } \\
\text { count } \\
(\mathrm{cfu} / \mathrm{mL})\end{array}$ & $\begin{array}{l}\text { Viable } \\
\text { Spore } \\
\text { Count } \\
(\mathrm{cfu} / \mathrm{mL})\end{array}$ & $\begin{array}{l}\% \\
\text { Sporulation }\end{array}$ & $\begin{array}{l}\text { Inhibition } \\
\begin{array}{l}\text { Zone } \\
\text { Diameter } \\
(\mathrm{mm})\end{array}\end{array}$ & $\begin{array}{l}\mathrm{LC} \mathrm{C}_{50} \\
(\mathrm{mg} / \mathrm{L})\end{array}$ & $\begin{array}{l}\text { Growth } \\
\text { rate } \\
(\mathrm{cfu} / \mathrm{L} . \mathrm{h})\end{array}$ \\
\hline 0 & $8.30 \times 10^{11}$ & $8.25 \times 10^{11}$ & 99 & 2.10 & 0.268 & $3.70 \times 10^{10}$ \\
1 & $8.30 \times 10^{11}$ & $8.24 \times 10^{11}$ & 99 & 4.15 & 0.257 & $3.75 \times 10^{10}$ \\
2 & $8.10 \times 10^{11}$ & $8.08 \times 10^{11}$ & 99 & 5.95 & 0.237 & $3.65 \times 10^{10}$ \\
3 & $7.45 \times 10^{11}$ & $7.42 \times 10^{11}$ & 99 & 8.05 & 0.210 & $3.53 \times 10^{10}$ \\
4 & $6.00 \times 10^{11}$ & $5.90 \times 10^{11}$ & 98 & 4.04 & 0.247 & $3.47 \times 10^{10}$ \\
5 & $5.70 \times 10^{11}$ & $5.67 \times 10^{11}$ & 99 & 3.03 & 0.288 & $3.37 \times 10^{10}$ \\
\hline
\end{tabular}

Note: The basal medium was composed of beef extract, $3 \mathrm{~g} / \mathrm{L} ;$ peptone, $5 \mathrm{~g} / \mathrm{L} ; \mathrm{NaCl}, 8 \mathrm{~g} / \mathrm{L}$ and glucose, $10 \mathrm{~g} / \mathrm{L}$

Table 4: Effect of different $\mathrm{KH}_{2} \mathrm{PO}_{4}$ concentrations on growth characteristics of $B$. thuringiensis

\begin{tabular}{lllllll}
\hline $\begin{array}{l}\mathrm{KH}_{2} \mathrm{PO}_{4} \\
\text { conc. }(\mathrm{g} / \mathrm{L})\end{array}$ & $\begin{array}{l}\text { Viable Cell } \\
\text { Count } \\
(\mathrm{cfu} / \mathrm{mL})\end{array}$ & $\begin{array}{l}\text { Viable } \\
\text { Spores } \\
\text { Count } \\
(\mathrm{cfu} / \mathrm{mL})\end{array}$ & $\begin{array}{l}\text { \% Sporulation } \\
\text { (11 }\end{array}$ & $\begin{array}{l}\text { Inhibition } \\
\begin{array}{l}\text { Zone } \\
\text { Diameter } \\
(\mathrm{mm})\end{array}\end{array}$ & $\begin{array}{l}\mathrm{LC}_{50} \\
(\mathrm{mg} / \mathrm{L})\end{array}$ & $\begin{array}{l}\text { Growth rate } \\
\text { (cfu/L.h) }\end{array}$ \\
\hline 0 & $7.48 \times 10^{11}$ & $7.45 \times 10^{11}$ & 99 & 8.05 & 0.210 & $3.53 \times 10^{10}$ \\
1 & $1.11 \times 10^{12}$ & $1.09 \times 10^{12}$ & 98 & 8.08 & 0.124 & $5.21 \times 10^{10}$ \\
2 & $1.13 \times 10^{12}$ & $1.11 \times 10^{12}$ & 98 & 10.05 & 0.115 & $5.21 \times 10^{10}$ \\
3 & $8.55 \times 10^{11}$ & $8.32 \times 10^{11}$ & 97 & 7.95 & 0.124 & $3.77 \times 10^{10}$ \\
4 & $8.68 \times 10^{11}$ & $8.40 \times 10^{11}$ & 97 & 7.85 & 0.204 & $3.67 \times 10^{10}$ \\
5 & $7.83 \times 10^{11}$ & $7.61 \times 10^{11}$ & 97 & 7.85 & 0.256 & $3.38 \times 10^{10}$ \\
\hline
\end{tabular}

Note: The basal medium was composed of beef extract, $3 \mathrm{~g} / \mathrm{L}$; peptone, $5 \mathrm{~g} / \mathrm{L} ; \mathrm{NaCl}, 8 \mathrm{~g} / \mathrm{L}$; yeast extract, $3 \mathrm{~g} / \mathrm{L}$ and glucose, $10 \mathrm{~g} / \mathrm{L}$

Table 5: Effect of different $\mathrm{MgSO}_{4}$ concentrations on growth characteristics of $B$. thuringiensis

\begin{tabular}{lllllll}
\hline $\begin{array}{l}\text { Conc. of } \\
\mathrm{MgSO}_{4} \\
(\mathrm{~g} / \mathrm{L})\end{array}$ & $\begin{array}{l}\text { Viable Cell } \\
\text { Count } \\
(\mathrm{cfu} / \mathrm{mL})\end{array}$ & $\begin{array}{l}\text { Viable Spore } \\
\text { Count } \\
(\mathrm{cfu} / \mathrm{mL})\end{array}$ & \% Sporulation & $\begin{array}{l}\text { Inhibition Zone } \\
\text { Diameter }(\mathrm{mm})\end{array}$ & $\mathrm{LC}_{50}(\mathrm{mg} / \mathrm{L})$ & Growth rate $(\mathrm{cfu} / \mathrm{L} . \mathrm{h})$ \\
\hline 0 & $1.12 \times 10^{12}$ & $1.09 \times 10^{12}$ & 97 & 10.05 & 0.115 & $5.21 \times 10^{10}$ \\
1 & $1.19 \times 10^{12}$ & $1.15 \times 10^{12}$ & 97 & 10.10 & 0.100 & $5.37 \times 10^{10}$ \\
2 & $1.17 \times 10^{12}$ & $1.13 \times 10^{12}$ & 96 & 10.10 & 0.101 & $5.50 \times 10^{10}$ \\
3 & $1.14 \times 10^{12}$ & $1.11 \times 10^{12}$ & 97 & 10.00 & 0.108 & $5.42 \times 10^{10}$ \\
4 & $1.13 \times 10^{12}$ & $1.10 \times 10^{12}$ & 97 & 10.03 & 0.109 & $5.42 \times 10^{10}$ \\
5 & $9.35 \times 10^{11}$ & $9.29 \times 10^{11}$ & 99 & 09.83 & 0.200 & $3.94 \times 10^{10}$ \\
\hline
\end{tabular}

Note: The basal medium was composed of beef extract, $3 \mathrm{~g} / \mathrm{L} ;$ peptone, $5 \mathrm{~g} / \mathrm{L} ; \mathrm{NaCl}, 8 \mathrm{~g} / \mathrm{L}$; yeast extract, $3 \mathrm{~g} / \mathrm{L}$, glucose, $10 \mathrm{~g} / \mathrm{L}$ and $\mathrm{KH}_{2} \mathrm{PO}_{4}, 2 \mathrm{~g} / \mathrm{L}$ 
Table 6: Effect of medium pH on growth characteristics of Bacillus thuringiensis

\begin{tabular}{llllll}
\hline $\begin{array}{l}\text { Initial pH of } \\
\text { Medium }\end{array}$ & $\begin{array}{l}\text { Viable Cell Count } \\
(\mathrm{cfu} / \mathrm{mL})\end{array}$ & $\begin{array}{l}\text { Viable Spores } \\
\text { Count }(\mathrm{cfu} / \mathrm{mL})\end{array}$ & \% Sporulation & $\begin{array}{l}\text { Inhibition Zone } \\
\text { Diameter }(\mathrm{mm})\end{array}$ & $\mathrm{LC}_{50}(\mathrm{mg} / \mathrm{l})$ \\
\hline 5 & $1.17 \times 10^{12}$ & $1.14 \times 10^{12}$ & 97 & 10.07 & 0.103 \\
6 & $1.24 \times 10^{12}$ & $1.22 \times 10^{12}$ & 98 & 10.05 & 0.101 \\
7 & $1.30 \times 10^{12}$ & $1.26 \times 10^{12}$ & 97 & 10.04 & 0.096 \\
8 & $1.14 \times 10^{12}$ & $1.05 \times 10^{12}$ & 92 & 10.05 & 0.104 \\
9 & $1.09 \times 10^{12}$ & $1.00 \times 10^{12}$ & 92 & 9.75 & 0.11 \\
\hline
\end{tabular}

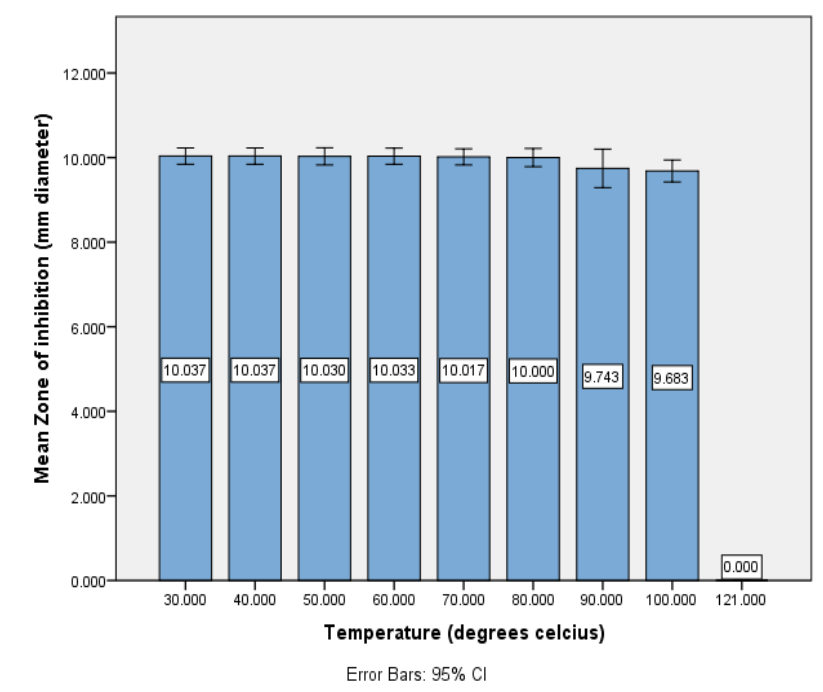

Figure 1: Effect of temperature (heat) on antimicrobial activity of CFS from optimum medium.

Note: The medium was composed of beef extract, $3 \mathrm{~g} / \mathrm{L}$; peptone, $5 \mathrm{~g} / \mathrm{L} ; \mathrm{NaCl}, 8 \mathrm{~g} / \mathrm{L}$; yeast extract, $3 \mathrm{~g} / \mathrm{L} ; \mathrm{KH}_{2} \mathrm{PO}_{4}, 2 \mathrm{~g} / \mathrm{L} ; \mathrm{MgSO}_{4}, 1 \mathrm{~g} / \mathrm{L}$ and Glucose, $5 \mathrm{~g} / \mathrm{L}$.

\section{References}

Abbott, W. S. (1925). A method of computing the effectiveness of an insecticide. J. Econ. Entomol. 18: 65-267.

Abriouel, H., Franz Ch M.A.P., Omar, N.B., Galvez, A. (2011). Diversity and applications of

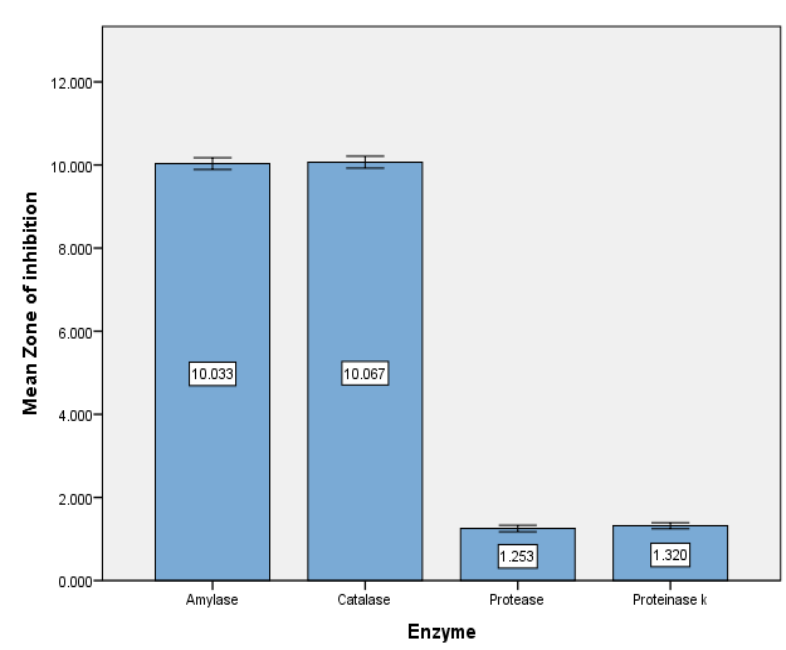

Figure 2: Effect of enzyme treatment on antimicrobial activity of CFS from optimum medium.

Note: The medium was composed of beef extract, $3 \mathrm{~g} / \mathrm{L}$; peptone, $5 \mathrm{~g} / \mathrm{L} ; \mathrm{NaCl}, 8 \mathrm{~g} / \mathrm{L}$; yeast extract, $3 \mathrm{~g} / \mathrm{L}$; $\mathrm{KH}_{2} \mathrm{PO}_{4}, 2 \mathrm{~g} / \mathrm{L} ; \mathrm{MgSO}_{4}, 1 \mathrm{~g} / \mathrm{L}$ and Glucose, $5 \mathrm{~g} / \mathrm{L}$.

Bacillus bacteriocins. FEMS Microbiol. Rev. 35: $201-232$.

Ahern, M., Verschueren, S., Van Sinderen, D. (2003). Isolation and characterisation of a novel bacteriocin produced by Bacillus thuringiensis strain B439. FEMS Microbiol. Lett. 163: 229-236.

Anderson, R.K.I. and Jayaraman, K. (2003). Influence of carbon and nitrogen sources on the 
growth and sporulation of Bacillus thuringiensis var Galleriae for biopesticide production. Chem. Biochem. Eng. Q 17 (3): 225-231.

Argolo-Filho, R. C. and Loguercio, L. L. (2014). Bacillus thuringiensis is an environmental pathogen and host-specificity has developed as an adaptation to human-generated ecological niches. Insects 5: 62-91

Bravo, A., Likitvivatanavong, S., Gill, S. and Soberon, M. (2011). Bacillus thuringiensis: a story of a successful bio-insecticide. Insect Biochem. Mol. Biol. 41: 423 - 431.

Cherif, A. Ouzari, H. Daffonchio, D. Cherif, H. Ben Slama, K. Hassen, A. Jaoua, S. and Boudabous, A. (2001). Thuricin 7: a novel bacteriocin produced by Bacillus thuringiensis $B M G 1.7$, a new strain isolated from soil. Lett. Appl. Microbiol. 32: 243-247

Dulmage, H. D. (1970). Insecticidal activity of HD-1, a new isolate of Bacillus thuringiensis var. alesti, J. Invertebr. Pathol. 15: 232-239.

Fuente-Salcido, D.N., Alanis-Guzman, M.G., Bideshi, D.K., Salcedo-Hernandez, R., BautistaJusto, M., Barboza Corona, J.E (2008). Enhanced synthesis and antimicrobial activities of bacteriocins produced by Mexican strains of Bacillus thuringiensis. Arch. Microbiol. 190: 633 -640 .

Gray, E. J., Lee, K. D., Souleimanov, A.M., Di Falco, M.R., Zhou X, Ly. A., Charles, T.C., Driscoll, B.T., and Smith, D.L. (2006). A novel bacteriocin, thuricin 17 , produced by plant growth promoting rhizobacteria strain Bacillus thuringiensis NEB17: isolation and classification. J. Appl. Microbiol. 100(3):545-554.

Kouser, S. and Qaim, M. (2011). Impact of Bt cotton on pesticide poisoning in small holder agriculture: a panel data analysis. Ecol. Econs. 70: $2105-2113$.
Kumar, S., Chandra, A and Pandey, K.C. (2008). Bacillus thuringiensis (Bt) transgenic crop: An environment friendly insect pest management strategy. J. Environ. Biol. 29: 641 - 653 .

Miller, G.L. (1972). Use of dinitrosalicyclic acid reagent for determination of reducing sugar. Biotechnol. Bioeng. Symp. 5: $193-219$.

Obeta, J.N. and Okafor, N. (1984). Medium for the production of primary powder of Bacillus thuringiensis subsp. israelensis. Appl. Environ. Microb. 47: 863-867.

Ozgur, A. Yenidünya, A. F. Sebnem, H. and Hatice, G. (2005). Isolation and characterization of Bacillus thuringiensis strains from different grain habitats in Turkey. World J. Microb. Biot. 21(3): 285-292.

Paik, H. D. Bae, S. and Pan, J.G. (1997). Identification and partial characterization of tochicin, a bacteriocin produced by Bacillus thuringiensis subsp. tochigiensis. J. Ind. Microbiol. Biot. 19: 294-298.

Palma, L., Munoz, D., Berry, C., Murillo, J., and Cabaliero, P. (2014). Bacillus thuringiensis toxins* An overview of their biocidal activity. Toxins 6: 3296-3325.

Sarrafzadeh, M. H. (2012). Nutritional requirements of Bacillus thuringiensis during different phases of growth, sporulation and germination evaluated by Plackett-Burman method. Iran. J. Chem. Eng. 31(4): 131-136

Siegwart, M., Graillot, B., Lopez, C.B., Besse, S., Bardin, M., Nicot, P.C. and Lpoez - Ferber, M. (2015). Resistance to bio-insecticides or how to enhance their sustainability: a review. Front. In Plant Sci. 6: 1 - 19. 
Stein, T. (2005). Bacillus subtilis antibiotics: structure, synthesis and specific functions. Mol. Microbiol. 56: 845-857.

Shunemann, R., Knaak, N., Fiuza, L. M. (2014). Mode of action and specificity of Bacillus thuringiensis toxins in the control of caterpillars and stink bugs in soybean culture. ISRN Microbiol v. 2014:135675 doi: 10.1155/2014/135675.

Tagg, J.R. and McGiven, A. R. (1971). Assay system for bacteriocins. Appl. Microbiol. 21: 943.

Tay W.T., Mahon, R.J., Heckel, D.G.., Walsh, T.K.., Downes, S., James, W.J. et al (2015). Insect resistance to Bacillus thuringiensis toxin cry $2 A b$ is conferred by mutations in an $A B C$ transporter subfamily protein A protein PloS Genet 11(11): e1005534 doi: 10.1371/journal.pgen. 1005534.

Zeinat, K. M., Nashwa, A. H., Fetyan, A., Mohamed, A.I., and Sherif, E. (2008). Biodegradation and detoxification of malathion by $B$. thuringiensis MOS-5. Aus. J. Bas. Appl. Sci. 2: $724-728$.

Zhong, X.T., Zhang, Q., Lin, K.., Yuan, C.H., Li, K.,. Jia, B.H., Che, Z.M., and Xiang, W.L. (2013). Optimization of bacteriocin-like substance production by Bacillus cereus $\mathrm{XH} 25$ using response surface methodology. Res. J. Biotechnol. 8:42- 48. 